\title{
The Essence of Remedial Secession: From the Perspectives of Human Right and Preservation of Natural Resources
}

\author{
Yonas Girma Adimassu $(\mathbb{1}$ \\ Public Law, Selcuk University, Konya, Turkey \\ Email: 154134001006@lisansustu.selcuk.edu.tr, yonasadimassu@gmail.com
}

How to cite this paper: Adimassu, Y. G. (2021). The Essence of Remedial Secession: From the Perspectives of Human Right and Preservation of Natural Resources. Beijing Law Review, 12, 1252-1267. https://doi.org/10.4236/blr.2021.124064

Received: April 8, 2021

Accepted: December 21, 2021

Published: December 24, 2021

Copyright ( 2021 by author(s) and Scientific Research Publishing Inc. This work is licensed under the Creative Commons Attribution International License (CC BY 4.0).

http://creativecommons.org/licenses/by/4.0/

\section{(c) (i) Open Access}

\begin{abstract}
Despite the growing separatist and autonomy movements throughout the world, the international legal framework appears to support unilateral secession as a response to any coercive conduct of a parent state. Due to historical challenges and wars, new states have recently been formed by secession from their parent nations. From the standpoint of human rights and natural resources, international legal instruments and judicial precedents must be investigated in remedial secession. It is critical to address the question of whether a single ethnic group may claim remedial secession if they suffer all of the (environmental or other) ills caused by the exploitation of natural resources but receive none of the benefits. This article attempts to address these and related topics.
\end{abstract}

\section{Keywords}

Remedial Secession, Natural Resource, Constitutional Law, Self-Determination

\section{Introduction}

In recent years, separatist and autonomy movements have grown fast across the world, and in certain nations, the classic war of independence has been conducted to fulfill the right to secession (Saideman, 1997). The majority of newly born states challenged their parent state and either prevailed or generated political pressure to win their new status (Saideman, 1997). However, if international law had clear legal rules on the topic of forming new nations through the right of secession, the recent brutal conflict would not have occurred for the birth of several countries such as Eritrea, South Sudan, Kosovo, and Bangladesh. 
Some of the recently developing causes that incite current separatist inclinations include claims for an equal distribution of natural resources, the quest for sufficient protection of democratic ideals and human rights, and the goal of adequate power allocation (Bannon, 2003). Once a group (tribal, indigenous, or ethnic) identifies itself as people by separating itself from the entire population of a country and requests from the central government for self-administration, autonomy or power-sharing, the allegation of that group can be treated as a claim of internal self-determination. Most countries try to accommodate external self-determination by applying the principle of self-rule and shared rule, which are constituent elements of the federal system. ${ }^{1}$ The principles of a national economic strategy with the assistance of decentralized fiscal rules and self-administration may solve the problems related to the un-equitable share of natural resources within a state. Nonetheless, the quest for an equitable share of natural resources is still one of the triggering factors for external self-determination.

Many countries don't readily accept the split of an integral part of their territory and people by one or another way. The international legal regime is more concerned with addressing the aspirations of nations by establishing standards that defend territorial integrity and sovereignty rather than secessionism at least in theory (Carley, 1996). The diverse kinds of literature regarding the right to self-determination in light of the international legal instruments create a clear question of whether secession (external self-determination) is permissible in the international legal framework. This article has addressed the following issues: What is the theory of remedial secession? Are there precedents that may support remedial secession? Should international law recognize a right of remedial secession? Could remedial secession apply to a situation where a group suffers all the (environmental or other) harms of exploiting natural resources but shares none of the benefits? The classical doctrinal legal research method has been employed to address these issues. Various books, domestic and international laws as well as cases are used to analyze the problems.

\section{Secession: Meaning and Taxonomy}

International law scholars provide various academic meaning beyond the etymological definition of secession as "the action of withdrawing from membership of a federation or body, especially a political state" (Anderson, 2004). For example, Marcelo Kohen defines secession as creating a new independent entity by separating part of the territory and population of an existing state without the latter's consent (Kohen, 2006). In contrast, James Crawford defines secession as the creation of a State by the use or threat to use force without the consent of the

${ }^{1} 40 \%$ of the world population are living in federal countries. Federalism is considered as one means of solving the conflicts related to self-administration, sharing of power and equitable distribution of natural resources. See, http://www.forumfed.org/countries/\#: :text=There $\% 20$ are $\% 20$ roughly $\% 2025 \% 20$ federal, $\% 2 \mathrm{C} \% 20 \mathrm{Br}$ azil\%2C\%20Germany\%20and\%20Mexico. Accessed on April 26, 2017. 
former sovereign (Crawford, 2007). Both definitions are not comprehensive enough to provide appropriate meaning of secession. There is no international legal instrument that offers a proper sense for "secession". Van den Driest defines secession in a middle course as follows:

"Establishment of newly independent state via the withdrawal of an integral part of the territory of an existing state, carried out by the resident population of that part of the territory, with or without the consent of the parent state or domestic constitutional authorization." (Driest, 2013)

Based on the above definition, secession can be categorized into Unilateral Secession, Constitutional Secession and Consensual Secession.

Unilateral secession is the establishment of a new sovereign state through the exit of some part of the territory of an existing state over the objection of the parent state (Milena, 2018). Either the parent state's consent or the domestic constitutional authorization may not be taken to carry out unilateral secession. Remedial secession is a type of unilateral secession that is carried out as an outright measure for the tyranny, human rights abuse or segregation from participating in developmental or governance systems of the parent state. The Secession of Kosovo from Serbia is one example of unilateral secession.

Constitutional secession is the establishment of a new independent state through the withdrawal of an integral part of the territory of an existing state through exercising the constitutional right of secession. Although many states oppose secession, few countries include a provision for secession in their constitutions. The 1974 Constitution of the Socialist Federal Republic of Yugoslavia (SFRY) was the first constitution that recognized the right of its "nations" to self-determination, including the right to secession (The Constitution of the Socialist Federal Republic of Yugoslavia, Extracts, 1974). The 1977 USSR constitution under article 72 incorporated the right to secession (The 1977 USSR constitution article 72). ${ }^{2}$ The recent and existing constitution that recognized secession is the 1995 Ethiopian constitution. The 1995 Ethiopian constitution, article 39, stated that every nation, nationality, and Ethiopia have an unconditional right to self-determination up to secession (The Constitution of the Federal Democratic Republic of Ethiopia, article 39). These constitutions have not set the existence of harm, dominancy, exploitation of natural resources without sharing the benefits as conditions for the secession of the so-called nations (ethnic groups). On the other hand, some countries, such as Turkey, openly condemn secessionism

\footnotetext{
${ }^{2}$ See http://www.departments.bucknell.edu/russian/const/77cons03.html\#chap08 retrieved at 4/4/2017. The constitutive law of Russia recognizes in its preamble and Article 5 (3) peoples with a right to self-determination "in the Russian federation". Arguably, the qualification "in the Russian Federation" circumscribes the right to self-determination to its internal aspect, this interpretation however is not evidenced by the Provisions in the preamble. Constitution of the Russian Federation, http://www.constitution.ru/en/10003000-01.htm (last visited at 04/04/2017)

${ }^{3}$ For-instance, article 3 of the Turkish constitution states that the Turkish territory is indivisible, Turkish language is official language and the state is secular. That provision is not subject to any amendment or proposes for amendment. Such entrenchment of indivisibility of territorial integrity is apparent denouncement of the secessionist approach.
} 
as a threat to their territorial integrity. Turkey explicitly recognizes the indivisibility of national territory in its constitutional framework (The 1982 Constitution of Turkey, article 3$).^{3}$

Consensual secession is establishing a new independent state through the withdrawal of some part of the territory of an existing state both by consenting the resident population of that part of the territory and the parent state, for example, the formation of South-Sudan by exiting from the republic of Sudan is a conversational type of secession. Eritrean secession in 1993 through a referendum was also carried out after getting the consent of the then Ethiopian government. However, the permission of a parent state is not often taken from the people through a referendum; rather, it is a political decision passed by either the national parliament or the head of government. In most of the consensual secessions globally, the parent state agreed after the war, regime change or influence of international communities.

\section{Remedial Secession in International Law and Precedents}

International law neither permits ${ }^{4}$ nor prohibits "secession" explicitly (General Comments Adopted by the Human Rights Committee, No. 12, The Right To Self-Determination (art. 1) [1984], 134, para. 4, UN Doc HRI/GEN/1/Rev.6 [General Comment No. 12). But, by the principle of equal rights and self-determination of peoples enshrined in the Charter of the United Nations, all peoples have the right freely to determine, without external interference, their political status and pursue their economic, social and cultural development (UN General Assembly, Declaration on Principles of International Law concerning Friendly Relations and Cooperation among States in accordance with the Charter of the United Nations, 24 October 1970, A/RES/2625 (XXV)). Every State must respect this right under the provisions of the Charter. However, constitutional and voluntary secession are not addressed by international law. If a new state is formed based on the consent of a parent state, the international law tends to provide favorable conditions to recognize the new State. That clearly shows that; states may waive their territorial integrity and sovereignty without conditions. However, there is no explicit legal rule which prohibits a third state/body/international organ from directly interfering or coercing through various means on a parent state to agree with the secession of an integral part of their territory. However, there is an implied provision from the unfriendly relations declaration of 1970, article 5 (8) which holds that every state shall refrain from any action aimed at the partial or total disruption of the national unity and territorial integrity of any other State or country. ICJ interprets this provision as every state shall refrain from affecting the territorial integrity of another state (Marxsen, 2015). The friendly relations declaration does not prohibit internal revolt of groups to self-determination; rather, it forbids the third countries threat to the sove${ }^{4}$ The Covenants and the General Comment 12 of the Human Rights Committee on the implementation of the right do not explicitly enunciate the external component of self-determination. 
reignty of another state. That means the friendly relations declaration nor any other international law have a stand on prohibiting any domestic revolt or protesting to claim secession as a remedy for internal grievance against grave human rights violation. The U.N. declaration on indigenous people's rights insertion of the right to self-determination does not imply the recognition of external self-determination or secession (Anaya, 2006). ${ }^{5}$

There is no clear precedent in the international legal system that allows directly exercising the right to remedial secession. However, the "right to self-determination which enshrined in many international covenants, gets a narrow interpretation by the General Assembly of United Nations to avert colonization (GA Res. 55/141 of 8 December 2000). ${ }^{6}$ For instance, the reports of the General Assembly of the United Nations" $3^{\text {rd }}$ Committee adopted a resolution on the right of the Palestinian people to self-determination, which seeks to provide support to "peoples under colonial, foreign or alien occupation" and to "sovereign peoples and nations". Moreover, the general assembly's resolution in 1999 was also reluctant to express the wording of "human rights problem" for the involvement of the U.N. interim peacekeeping mission in Kosovo (UN General Assembly, Situation of human rights in Kosovo: resolution/adopted by the General Assembly, 29 February 2000, A/RES/54/183). Indeed, the political motives are presented as justifications for state recognition in the guise of remedial secession rather than the legal basis. It has been observed in Kosovo, Palestine, and Somaliland cases.

Even though there is no precedent in the positive validation of remedial secession in international law, there are precedents regarding the criteria, thresholds, and processes of remedial secession in international tribunals and domestic judicial interpretations such as Aaland Island, Kosovo and Quebec (Sammen, 2010).

The second Commission of Rapporteurs on the Aaland Island Vs Finland case specified while there was no general right to secede, the

"Separation of a minority from the State of which it forms part and its incorporation into another State may only be considered as an altogether exceptional solution, a last resort when the State lacks either the will or the power to apply just and effective guarantees." (Meller, 2012)

It shows that the process and reasons used by the League of Nations about why the Aaland Island does not secede from Finland contained elements of remedial secession doctrine (Steven, 2016). Hence, if the State is unwilling or unable to guarantee just and effective internal self-governance and human rights

${ }^{5}$ A delegate of Guatemala to the 1999 UN working group to the declaration of indigenous people's rights summarizes the discussion on the right to self-determination that the right to self-determination should not be to the detriment of independent and territorial integrity of states. ${ }^{6}$ During its fifty-fifth session in 2000, the General Assembly adopted reports of the Special Political and Decolonization Committee (Fourth Committee) and individual resolutions on Western Sahara, New Caledonia, and Tokelau, as well as a comprehensive resolution on American Samoa, Anguilla, Bermuda, the British Virgin Islands, the Cayman Islands, Guam, Montserrat, Pitcairn, St. Helena, the Turks and Caicos Islands and the United States Virgin Islands. 
protection, the minority in that State may exercise secession unilaterally. Furthermore, secession would be used as a last resort to solve the lack of reasonable and adequate rights protection. Thus, it is the first precedent regarding the threshold of remedial secession.

ICJ advisory body's statement skips the question: Does the unilateral declaration of independence recognized by international law by the Provisional Institutions of Self-Government of Kosovo. The process and the advisory body's indication about the authors' identity of the declaration of independence (G.A. Res. 63/3, U.N. Doc. A/RES/63/3 (Oct. 8, 2008)) can be taken as a precedent for the condition of unilateral secession. Indeed, the entire and statement of ICJ's advisory body cannot be considered a precedent to the legality of remedial secession in international law.

The African Union seems to be more concerned with the territorial integrity of states than remedial secession of ethnic/tribal groups. For instance, Africa Union denies recognition of the de-facto State of Somali land, which declared independence from Somalia in 1991 because of former Somalia's Ziadbare regime violation of fundamental human rights to the people of Somaliland. ${ }^{7}$ The A.U.'s reluctance to provide legitimacy for Somaliland seems that it is concerned not to set a precedent for other secessionist groups in Africa.

To summarize, there are no international law and judicial precedent to allow remedial secession yet. On the contrary, the independence of states in recent world history and the reaction of international law and judicial machinery indicate the de-facto validity of unilateral secession.

\section{Who Is Entitled to Exercise It?}

Both ICCPR and ICESCR use the word "people" to represent a right holder of self-determination. Who are people in the context of these international documents? The negotiations done before the adoption of these conventions reflected that people do not denote ethnic minorities or any other particular group within a state; rather, it represents the whole people of a state broadly (Bossuyt, 1987). According to Marcelo Kohn, the first to be recognized as peoples are the peoples of Nations depending on the U.N. practice that relied on territorial entities with historical or administrative background, thus favoring the formula "un Etat = un people" (Kohen, 2006). It implies that the right of self-determination stipulated in international human rights instruments is vested in the whole people of a particular state.

Nevertheless, the U.N. declaration on the rights of indigenous people came across a distinct approach regarding people who are entitled to exercise the right to self-determination through the internal aspect of self-determination. Indigenous communities are another category of people apart from or beside the whole people of a country. As a result, indigenous communities have the status ${ }^{7}$ Only 6 countries including Ethiopia and Belgium recognized Somaliland as a state till 2017. https://ke.boell.org/sites/default/files/somaliland_statehood_recognition_and_the_ongoing_dialogu e_with_somalia.pdf (available April 6, 2017). 
of people within and independently from "a broader national people" concerning the context of interpreting the U.N. declaration on the right of indigenous people.

What would be the application of international law if the State recognizes a specific group as a people? For example, the Bosnia-Herzegovinian constitution recognizes Bosniacs, Bosnian Serbs and Croats as constituent people (The constitution of Bosnia Herzegovina, 1994). Could Bosnians Serbs or Croats claim the right to self-determination, stipulated in international human rights covenants, because the host state recognizes the group as a people? I argue that, as far as the host state recognizes a specific group as a people, the international tribunals should not frame the issue about whether that group is a people or not. Suppose a particular state as "a defendant" admits the status of a group as people. In that case, the group should be considered people internationally and entitled to claim the rights bestowed to people.

The ACHPR's decision on the case between "the people of southern Cameroon" Vs, "the republic of Cameroon" defines "people" as the manifestation of numerous characteristics and affinities, including shared history, linguistic tradition, and territorial tradition connection, and political outlook (266/03, African Commission on Human and Peoples' Rights (ACHPR) Kevin Mgwanga Gunme et al./Cameroon (2009), AHRLR 9 (ACHPR), Para 179) Moreover, ACHPR signifies "People" for those who "identify themselves as a people with a separate and distinct identity and that identity are an innate characteristic" within "a people". Therefore, indigenous communities and other marginalized or vulnerable groups not taking part in the natural resource subject to exploitation by the state mainstream developmental paradigm are considered "people" besides the whole people of a state (De Feyter, 2015).

However, there is no unambiguous definition of "people" in the international legal framework, particularly in the African perspective. The ACHPR's purpose for people is still subjective and open to diverse interpretations. For instance, among the criteria set by ACHPR to identify "people", the commencement of history to distinguish one people from the other is not clear yet and challenging to find a common political outlook in the presence of individual political freedom would create subjectivity in defining it. Generally, in multiethnic Africa, the characteristics bestowed to the African commission's term "people" would make an overlap of various claimants, leading to extreme fragmentation and cleavage within the continent.

\section{Remedial Secession: Specific Elements}

Secession can take place with or without the agreement of the parent state. A unilateral secession is a form of state restructuring in which a new state extracts some land against the objections of its parent state. Remedial secession is a sort of unilateral secession that can occur after a group of people has been subjected to injustice. 
Where a breach of internal self-determination has occurred, the afflicted people may exercise to separate from the intimidating state to remedy this situation by the pursuit of remedial secession (Glen, 2013). There is no universally agreed definition of remedial secession. Some scholars define remedial secession in terms of specific conditions including the existence of prior approval of a parent state. Van Der Driest defines remedial secession as the establishment of a newly independent state by withdrawing an integral part of the territory from an existing state carried out by the resident population of that part of the territory, without the consent of the present State or domestic constitutional authorization, yet as a remedy of last resort to the severe injustices. Two essential elements are added with unilateral secession as drawn from the above definition: grave Injustice and last resort to serious Injustice. It is crucial to define what grave injustice is?

\subsection{Grave Injustice as Validation}

The phrase grave injustice comprises two elements that imply the gravity of the act and the harmfulness or prejudice. Although the term "serious injustice" is subjective and open to broad interpretation, many scholars provide meaning. Grave Injustice concerning remedial secession can be understood as widespread violations of fundamental human rights of the members of that people, exploitation of natural resources with racial/ethnic discrimination in terms of sharing the benefits, and serious violation or denial of the right of internal self-determination of the people (Kohen, 2006). The post-injustice character of remedial secession is one of the shortcomings of remedial secession (Vidmar, 2010). The existing literature about remedial secession seems to show that an ethnic/tribal group is required for waiting until the occurrence of injustice to take a measure of remedial secession. Remedial secession should be allowed to a specific people whenever grave injustice would be imminent to harm the people. For instance, if the government enacts domestic law that would seriously damage a specific group and if the occurrence of that harmful act is imminent to occur, that group should be entitled to exercise remedial secession subject to exhausting other alternative available remedies. There are different elements of grave injustice. For this article, I have selected, among other things, human rights violations, and natural resource exploitation as parts of remedial secession.

\subsubsection{Human Right Violation as Grave Injustice}

What makes violation of human rights to be grave or widespread? The seriousness or gravity of Injustice depends on the socio-economic and civil-political damage inflicted upon the victims. A state's deliberate and discriminatory infringement of fundamental rights of members of a specific group or a group itself can be considered as injustice. However, no objective criterion makes a specific injustice label it as grave or minor. The other issue is related to why remedial secession is unilateral for violation of fundamental human rights. What 
about the consent of the population of the parent state? The first argument is the morality of political decisions. In a democratic polity trend, most of the people within a parent state who decide to vote for a ruling party that creates Injustice on the specific ethnic group tacitly accepts that Injustice. Hence, the people who do not denounce the Injustice that happens to other members could not have a moral ground to determine the external self-determination of (the other people) victims of Injustice. Therefore, critical scrutiny on other political circumstances of that country's campaign, voting, and election system is necessary before blaming the voters. For example, suppose the other people fight together (peacefully) with the secessionists against the regime to avert severe Injustice. In that case, the unilateral act of secession could not be legitimate in fulfilling the conditions.

Thus, massive human right violation by the state authorities can be taken as a reason to legitimize or validate unilateral secession of an integral part of a state and population. Sometimes, the violent actions of secessionists get justification if the State violates the fundamental human rights of the group that requires separation. The lack of objective criteria to measure the graveness of any human right violation is a challenge in defining remedial secession.

\subsubsection{The Exploitation of Natural Resource without Sharing the Benefits} The principle of sovereignty and territorial integrity as part of the underlying principles of international law, states use these principles to defend the claims related to unilateral secession. Who has legal title over natural resources in international law? U.N. declaration on Permanent sovereignty over natural resources enables the State and the whole people of that State to have permanent sovereignty over natural resources (UN General Assembly, Permanent sovereignty over natural resources, 17 December 1973, A/RES/3171). As long as the term People represents the entire population of a state in the international legal system, a specific ethnic or tribal group will not have a sovereign right over natural resources through the resource belonging to that group. The constitutions of many countries also bestow sovereignty to the whole people and the nation besides controlling natural resources. But there are exceptions like Ethiopia, which under Article 8 of the 1995 constitution vests the sovereign power not to the nation's whole people but every ethnic group (nation, nationalities, and people). The constitution of Federal Democratic Republic of Ethiopia paradoxically provides the law-making power on utilization of natural resources to the federal government and administration of natural resources to regional states (article 55 and 52 of the1995 constitution of Ethipia). Even in the Ethiopian case, this shows that the sovereign right of ethnic groups is not extended up to its natural resources. It implies both the international legal framework and domestic legal systems are reluctant to provide the power of control/decision making over natural resources to a specific ethnic/tribal/local people. So, the available mechanism for concerned ethnic groups to ask for an equitable share of the benefit from natural resources through the right to development, a healthy envi- 
ronment, food, and other socio-economic rights (U.N. Committee on Economic, Social and Cultural Rights (CESCR), General Comment No. 12: The Right to Adequate Food (Art. 11 of the Covenant), May 12 1999).

According to the U.N. declaration on the right of indigenous people, they remarkably have the right to preserve, customarily utilize and develop their land and natural resource (United Nations Declaration on the Rights of Indigenous Peoples: resolution/adopted by the General Assembly, 2007, A/RES/61/295). Despite its non-binding effect, the U.N. declaration on indigenous people rights provides comprehensive protection to the natural resource of indigenous people (United Nations Declaration on the Rights of Indigenous Peoples: resolution/adopted by the General Assembly, 2007, A/RES/61/295). The ILO convention similarly shields the indigenous people from losing their ancestral heritage, land, and natural resources (ILO, Indigenous and Tribal Peoples Convention, C169, 1989). It seems the international law creates sovereignty over sovereignty concerning indigenous people and State over natural resources. Free, prior and informed consent of the people in concern is required before utilizing the help by the State. If the State violates this right by exploiting their natural resource without sharing the benefits can be referred to as an injustice to validate the remedy part of unilateral secession by the indigenous people.

The exploitation of natural resources without sharing the benefits to a specific ethnic group who are owners of that natural resource is a human right violation by itself. First, it is a violation of the right to equality which is enshrined in all human rights conventions in UDHR. Second, it is also a violation of the basic tenets of the U.N. Convention on the elimination of all forms of racial discrimination. Finally, it is also part of the injustices that harms the socio-economic life of the group.

The African Convention on conserving nature and natural resources provides procedural rights, including access to Justice in environmental claims and other issues. Through the domestic fiscal system or development strategies, countries might formulate principles related to utilizing natural resources by taking an equitable share of the benefits into consideration.

The international legal regime tends to allow remedial secession as a measure for colonization to prevent the colonizers' unjust acts against the colony (Glen, 2013). Some scholars argue that denial of internal self-rule is a contributing factor for external self-determination (Daniel, 2010). The Nobel Laureate Economist Buchanan once said the difference between colonizers and domestic dictators is that a body of saltwater separates them (Buchanan, 2004). One of the unjust acts of colonizers is that they exploit natural resources without sharing the benefits to the people of a colonized state. As far as the character of the domestic government is like the colonizers, the remedy (unilateral secession) which permitted to avoid the unjust act in the situation of colonization should have similarly been admitted to the victimized people or group. Therefore, international law should recognize the broader concept of remedial secession by considering 
the rationale behind allowing secession as decolonization, to be applied by analogy for domestic exploiters.

There are competitive ideas regarding the exploitation of natural resources as a justification for remedial secession. On the one hand, the phrase "available resource" (Feyter, 2017) might be taken to justify the protection of socio-economic rights in a country that promotes "national sovereignty over natural resources. On the other hand, the rights of indigenous people over natural resources compel states to limit their exploitative tendency over natural resources that belong to indigenous people or tribal groups. It implies that remedial secession, exploitation of natural resources belonging to an indigenous people might be justified in the guise of realizing the indigenous people's socio-economic rights. Unilateral secession as a remedy depends either on violation of individual rights or group rights if the two come into the picture of competition simultaneously. If “... available resource" exists to differentiate developing countries as a justification for non-protection or non-fulfilment of socio-economic rights, the protection of (these rights) individual rights will be realized on the cost of group rights." Otherwise, the State might defend against remedial secession for better protection of socio-economic rights by using natural resources if the secession is motivated by exploitation of natural resources of a specific group without taking part in the benefits. Indeed, the states' discriminatory act (in terms of exploiting natural resources) that affects a particular ethnic group (owner of the natural resource) can be one instance that shows the State commits abuse of the right to equality.

\subsection{Denial of Internal Self-Determination}

"The right to self-determination of a people is normally fulfilled through internal self-determination people's pursuit of its political, economic, social and cultural development within the framework of an existing state" (Schneiderman, 1999). ${ }^{8}$

As the right to self-determination is enshrined in the U.N. charter, international covenants, and other regional conventions, the ultimate beneficiary of this right is the entire State's people (Aureliu, 1981). The external aspect of self-determination stated in international conventions is either limited to decolonization or to shun military occupation. Internal self-determination is one dimension of self-determination; the people should benefit from political, social, economic, and cultural developments. That can be articulated both normatively and practically. The people without any ethnic/racial discrimination are proportionally represented in the national decision-making institutional systems. In the Quebec case, the supreme court of Canada indicates that the right to remedial secession occurs "when a people are blocked from the meaningful exercise of its right to self-determination internally" (Dumberry, 2006). However, one should

${ }^{8}$ This is a statement made by a judge in the supreme court of Canada about Quebec, taken from, Schneiderman, D. (1999) The Quebec Decision: Perspectives on the Supreme Court Ruling on Secession, James Lorimer \&amp; Company, 1 Jan., 168. 
primarily answer the question of "who are a people?" contextually articulating the entitlement of internal self-determination within a state.

Exceptionally, indigenous communities are allowed to exercise the right to self-determination besides the entire people. The Internal aspect of the right to self-determination guarantees the people to exercise the right over natural resources. It involves economic emancipation of the whole people in general and indigenous communities and later as a mechanism that preserves the natural resource from exploitation by the government without sharing the benefits to the people.

The international legal framework has provided neither the internal nor the external aspect of self-determination as of right within the State to a specific ethnic or minority group. As the right to self-determination is provided to all people, a particular ethnic group should first recognize "people" to claim self-determination. "You can use what you have," a classical moral principle applies to secessionist groups. This ethical principle implies that ethnic groups claiming to exercise internal self-determination apart from the whole people cannot do so because it belongs to them jointly and severally with the entire people of the State. However, the domestic constitutional provisions might provide this right to the groups. Some of the tenets of internal-self-determination considering devolution of power, fiscal decentralization, and equitable allocation of natural resources are enshrined in many federal and decentralized unitary states such as the U.K.

Moreover, by creating bi-cameral parliament, the interested ethnic groups/minorities might be represented in the national decision and rulemaking regarding their interest. Therefore, international law is generally unvoiced about interfering in the internal affairs of states, except trying to regulate or influence their internal self-rule/shared rule policy through international organizations like World Bank. Therefore, the universal declaration of democracy can be cited as a global move towards regulating the internal democratic values that involve the tenets of internal self-determination of ethnic groups or local minorities (Universal Declaration on Democracy, 1997). ${ }^{9}$ Although this declaration is not binding, it will have an indirect regulatory effect in the domestic governance policies to provide internal self-determination to local people.

\subsection{Unilateral Secession as Last Resort}

Unilateral secession as a last resort of corrective/remedial measure to the Injustice on the group is the second element of remedial secession. Ethnic/indigenous/tribal groups as victims of Injustice must use both domestic and internationally accessible normative, legal, peaceful institutional mechanisms to avert the Injustice (Assiatiani, 2013). Domestically, the group should use the judicial system as a means to seek Justice. Independence of the judiciary and other ${ }^{9}$ Article 23 of Universal declaration of human rights states that, Democratic institutions and processes must also foster decentralized local and regional government and administration, which is a right and a necessity, and which makes it possible to broaden the base of public participation. 
non-politicization of domestic justice machinery affect the remedies. Do alternative treatments include "violent remedies", for instance, violent protest (revolt) that destroys government institutions or properties, fighting an insurgent war to liberate the territory or coup d'état? The secessionist's use of violence has no legal ground. I agree with Olivier Corten and Georges Abi-Saab's argument that, as forcible repression, armed struggle or terrorism within the boundaries of one State is not governed by jus ad Bellum ${ }^{10}$, but by the domestic law of the State concerned (Abi-Saab, 1979). Instead, the united nation general assembly in the Kosovo case condemned any violent means that aims a unilateral secessionist arrangement (Security Council Resolutions 1160 (1998), 1199 (1998), 1203 (1998) and 1244 (1999)). The secessionists' use of violent methods would instead give the State the legitimacy force that would stifle their voice of secessionism. As far as armed struggle and violent revolt are concerned, whether the Injustice, which could be cited as the caveat of remedial secession, should wrap or not wrap the human rights violations that the State uses legitimately to avert the violent method of secessionists? Regarding this issue, the State might declare a state of emergency as a justification for derogation of human rights through the constitutional procedure. However, the international trend seems not to consider the human rights violations that could be committed to protecting the internal peace and order of the country through constitutional mechanisms.

\section{Conclusion}

There is no permissive provision in the present international legal system that allows a distinct ethnic/racial group to unilaterally split from another sovereign State by declaring itself a people as a remedy for exploiting natural resources without sharing benefits. Indeed, exploitation of natural resources without sharing gifts to the concerned ethnic group can be one element among other human rights violations, making the ethnic group legitimatize the unilateral remedial secession. The available global legal system seems unwilling to set a rule that allows unilateral secession for the claimant by any justifiable reason or not. That is because the principles of territorial integrity and state sovereignty would be jeopardized if unilateral secession had a place in the international legal framework.

International legal order should provide a balanced legal framework that allows for both remedial secession and the safeguarding of the territorial integrity of the state. Domestic tyranny in all socioeconomic and political domains is more dangerous to society's peace and security than the separation of an impor-

\footnotetext{
${ }^{10}$ Jus (or ius) ad bellum is the title given to the branch of law that defines the legitimate reasons a state may engage in war and focuses on certain criteria that render a war just. The principal modern legal source of jus ad bellum derives from the Charter of the United Nations, which declares in Article 2: "All members shall refrain in their international relations from the threat or the use of force against the territorial integrity or political independence of any state, or in any other manner inconsistent with the purposes of the United Nations"; and in Article 51: "Nothing in the present Charter shall impair the inherent right of individual or collective self-defense if an armed attack occurs against a Member of the United Nations." available in http://www.crimesofwar.org/a-Z-guide/jus-ad-bellum-jus-in-bello/ (last visited 05/04/2017)
} 
tant portion of a sovereign state. As a result, international law should establish a legal procedure that allows a specific group which bears the burden of economic or developmental segregation particularly denial from receiving an equitable benefit from its resource, to exercise external self-determination as an independent state through a remedial unilateral secession. Denial of internal self-determination can be a motivator for compulsive assertion of exterior self-determination.

\section{Conflicts of Interest}

The author declares no conflicts of interest regarding the publication of this paper.

\section{References}

Abi-Saab, G. (1979). Wars of National Liberation in the Geneva Conventions and Protocols. Recueil des cours 165; Secession: International Law Perspectives.

Anaya, J. (2006). The Human Right of Indigenous People. In F. G. Isa, \& K. Feyter (Eds.), International Protection of Human Rights: Achievements and Challenges (p. 604). University of Duesto, Humanitarian Net.

Anderson, L. M. (2004). The Institutional Basis of Secessionist Politics: Federalism and Secession in the United States. Publius, 34, 1-18. http://www.jstor.org/stable/3331204 https://doi.org/10.1093/oxfordjournals.pubjof.a005025

Assiatiani, S. (2013). Remedial Sessation under International Law, Analysis of Kossovo, Abkhazia and South Ossetia L.L.M. Human Right Thesis, Central European University. https://blogs.elpais.com/files/remedial-secession-asatiani_sopio.pdf

Aureliu, C. (1981). The Right to Self-Determination: Historical and Current Development on the Basis of United Nations Instruments, Special Rapporteur on the Right to Self-Determination. 7. https://digitallibrary.un.org/record/25252? ln=es

Bannon, P. (2003). Natural Resources and Violent Conflict Natural Resources and Violent Conflict Options and Actions. The World Bank.

https://reliefweb.int/sites/reliefweb.int/files/resources/AD9082E35AEFBF52492570000 01F2AC0-wb-gen-31aug.pdf

Bossuyt, M. J. (1987). Guide to the "Travaux Préparatoires" of the International Covenant on Civil and Political Rights. Brill|Nijhoff. https://brill.com/view/title/9771

Buchanan, A. (2003). Secession, Stanford Encyclopedia of Philosophy. The Metaphysics Research Lab, Stanford University, 3. https://plato.stanford.edu/entries/secession/

Buchanan, A. (2004). Justice, Legitimacy, and Self-Determination. Oxford University Press. https://doi.org/10.1093/0198295359.001.0001

Carley, P. (1996). Self-Determination: Sovereignty, Territorial Integrity, and the Right to Secession, Peaceworks, No. 7, 3.

https://www.usip.org/publications/1996/03/self-determination-sovereignty-territorial-i ntegrity-and-right-secession\#

Crawford, J. (2007). Secession. In J. R. Crawford (Ed.), The Creation of States in International Law (p. 9). Oxford University Press.

https://oxford.universitypressscholarship.com/view/10.1093/acprof:oso/9780199228423 .001.0001/acprof-9780199228423-chapter-9 
https://doi.org/10.1093/law/9780199228423.001.0001

Daniel, M. (2010). The International Court of Justice's Kosovo Case: Assessing the Current State of International Legal Opinion on Remedial Secession. Canadian Yearbook of International Law, 48, 215. https://doi.org/10.1017/S0069005800010122

Driest, F. (2013). Remedial Secession: A Right to External Self-Determination as a Remedy to Grave Injustices? Intersentia.

Dumberry, P. (2006). Lessons Learned from the Quebec Secession Reference before the Supreme Court of Canada. In M. Kohen (Ed.), Secession: International Law Perspectives (pp. 416-452). Cambridge University Press.

Feyter, D. (2015). The Right to Development in Africa. In E. Brems, C. Van der Beken, \& S. A. Yimer (Eds.), Human Rights and Development (p. 9). Brill Nijhoff.

Feyter, D. (2017). Differentiation between Developing and Developed Countries in International Law. University of Antwerp Blackboard.

https://blackboard.uantwerpen.be/webapps/blackboard/execute/content/file? cmd=view \&content $\mathrm{id}=12514121$ \&course $\mathrm{id}=37753 \quad 1$ \&framesetWrapped=true

Glen, A. (2013). Unilateral Non-Colonial Secession in International Law and Declaratory General Assembly Resolutions: Textual Content and Legal Effects. Denver Journal of International Law and Policy, 41, 345-395.

Gunme, K. M. et al. (2009). African Commission on Human and Peoples' Rights (ACHPRAHRLR 9 (ACHPR).

International Labour Organization (ILO), Indigenous and Tribal Peoples Convention, C169, June 27 1989, C169.

Kohen, M. G. (2006). Secession: International Law Perspective. Cambridge Univ. Press. https://doi.org/10.1017/CBO9780511494215

Marxsen, C. (2015). Territorial Integrity in International Law, Its Concept and Implications for Crimea. The Zeitschrift für ausländisches öffentliches Recht und Völkerrecht, 75, 7-26. https://www.zaoerv.de/75 2015/75 2015 1 a 7 26.pdf

Meller, S. (2012). The Kosovo Case: An Argument for a Remedial Declaration of Independence. University of Georgia, G.A. Res. 63/3, U.N. Doc. A/RES/63/3 (October 8, 2008).

Milena, S. (2018). Self-Determination and Secession under International Law: The Cases of Kurdistan and Catalonia. ASIL Insights, 22, 2.

Saideman, S. M. (1997). Explaining the International Relations of Secessionist Conflicts: Vulnerability versus Ethnic Ties. International Organization, 51, 721-753.

http://www.jstor.org/stable/2703504

https://doi.org/10.1162/002081897550500

Sammen, T. (2010). A Right to Remedial Secession? The Case of Kosovo and Its Implications for International Law. Universitetet i Oslo Det juridiske fakultet Kandidatnummer. https://www.duo.uio.no/bitstream/handle/10852/18802/101564.pdf? sequence $=1$

Schneiderman, D. (1999). The Quebec Decision: Perspectives on the Supreme Court Ruling on Secession. James Lorimer \& Company.

Steven, R. (2016). Towards "Never Again": Searching for a Right to Remedial Secession under Extant International Law. Buffalo Human Rights Law Review, 22, 261. https://digitalcommons.law.buffalo.edu/bhrlr/vol22/iss1/7

The Constitution of the Federal Democratic Republic of Ethiopia [Addis Ababa], August 211995.

The Constitution of the Federation of Bosnia and Herzegovina [Sarajevo], March 18 1994. 
The Constitution of the Republic of Turkey, Ankara, 7 November 1982.

The Constitution of the Socialist Federal Republic of Yugoslavia, Extracts, 1974, in H. Krieger (ed.), The Kosovo Conflict and International Law (2001), 2.

U.N. Committee on Economic, Social and Cultural Rights (CESCR), General Comment No. 12: The Right to Adequate Food (Art. 11 of the Covenant), May 121999.

U.N. General Assembly Res. 55/141 of December 8 2000. 55 GA Res. 55/142 of December 8 2000, GA Res. 55/143 of December 8 2000, GA Res. 55/144 of December 8 2000, GA Res. 55/87 of December 42000.

U.N. General Assembly, Declaration on Principles of International Law Concerning Friendly Relations and Cooperation among States Following the Charter of the United Nations, October 24 1970, A/RES/2625 (XXV).

U.N. General Assembly, Permanent Sovereignty over Natural Resources, December 17 1973, $A / R E S / 3171$.

U.N. General Assembly, United Nations Declaration on the Rights of Indigenous Peoples: Resolution/Adopted by the General Assembly, October 2 2007, A/RES/61/295.

UN General Assembly (2000, February 29). Situation of Human Rights in Kosovo: Resolution/adopted by the General Assembly. A/RES/54/183.

http://www.refworld.org/docid/3b00f5347.html

Universal Declaration on Democracy, Declaration Adopted without a Vote, by the Inter-Parliamentary Council At Its 161st Session, (Cairo, September 16 1997).

USSR Constitution Article 72, Available in Provisions in the Preamble. Constitution of the Russian Federation.

Vidmar, J. (2010). Remedial Secession in International Law: Theory and (Lack of) Practice. St Antony's International Review, 6, 37-56. http://www.jstor.org/stable/26227069 